\title{
Article \\ The Effect of Hydrogen Production Rate of the via Different Preparation of Co-Based Catalyst with Sodium Borohydride
}

\author{
Jyun-Lin Lai ${ }^{1}$, Win-Jet Luo ${ }^{1} \mathbb{D}$, Yean-Der Kuan ${ }^{2, * \mathbb{D}}$ and Pai-Jun Zhang $^{2}$ \\ 1 Graduate Institute of Precision Manufacturing, National Chin-Yi University of Technology, \\ Taichung City 41170, Taiwan; kevin_lai@chianyih.com.tw (J.-L.L.); wjluo@ncut.edu.tw (W.-J.L.) \\ 2 Department of Refrigeration, Air Conditioning and Energy Engineering, \\ National Chin-Yi University of Technology, Taichung City 41170, Taiwan; s4a916002@student.ncut.edu.tw \\ * Correspondence: ydkuan@ncut.edu.tw; Tel.: +886-4-23924505 (ext. \#8256)
}

Citation: Lai, J.-L.; Luo, W.-J.; Kuan, Y.-D.; Zhang, P.-J. The Effect of Hydrogen Production Rate of the via Different Preparation of Co-Based Catalyst with Sodium Borohydride. Catalysts 2021, 11, 528. https:// doi.org/10.3390/catal11050528

Academic Editors: Rei-Yu Chein and Wei-Hsin Chen

Received: 17 March 2021

Accepted: 19 April 2021

Published: 21 April 2021

Publisher's Note: MDPI stays neutral with regard to jurisdictional claims in published maps and institutional affiliations.

Copyright: () 2021 by the authors. Licensee MDPI, Basel, Switzerland. This article is an open access article distributed under the terms and conditions of the Creative Commons Attribution (CC BY) license (https:// creativecommons.org/licenses/by/ $4.0 /)$.

\begin{abstract}
This study processed the water vapor entrained in the $\mathrm{NaBH}_{4}$ hydrogen production reaction inside the primary hydrogen production tank through the secondary hydrogen production tank, in order to increase total hydrogen production. $\gamma-\mathrm{Al}_{2} \mathrm{O}_{3}$ was used as the carrier for the hydrolytic hydrogen production reaction in the primary hydrogen production tank. The reaction was chelated with metal catalyst $\mathrm{Co}^{2+}$ at different concentrations to produce the catalyst. Next, the adopted catalyst concentration and different catalyst bed temperatures were tested. The secondary hydrogen production tank was tested using $\mathrm{NaBH}_{4}$ powder and multiple $\mathrm{NaBH}_{4}+\mathrm{Co}^{2+}$ mixed powders at different ratios. The powder was refined by ball milling with different steel ball ratios to enlarge the contact area between the water vapor and powder. The ball milling results from carriers at different concentrations, different catalyst bed temperatures, $\mathrm{NaBH}_{4}+\mathrm{Co}^{2+}$ mixed powders in different ratios and different steel ball ratios were discussed as the hydrogen production rate and hydrogen production in relation to the hydrolytic hydrogen production reaction. The experimental results show that the hydrolytic hydrogen production reaction is good when $45 \mathrm{wt} \% \mathrm{Co}^{2+} / \gamma-\mathrm{Al}_{2} \mathrm{O}_{3}$ catalyst is placed in the primary hydrogen production tank at a catalyst bed temperature of $55^{\circ} \mathrm{C}$. When the $\mathrm{NaBH}_{4}+\mathrm{Co}^{2+}$ mixed powder in a ratio of 7:3 and steel balls in a ratio of 1:4 were placed in the secondary hydrogen production tank for $2 \mathrm{~h}$ of ball milling, the hydrogen production increased favorably. The hydrogen storage can be increased effectively without wasting the water vapor entrained in the hydrolytic hydrogen production reaction, and the water vapor effect on back-end storage can be reduced.
\end{abstract}

Keywords: sodium borohydride; catalyst; hydrogen; ball milling

\section{Introduction}

The demand for energy has increased and the dependence on fossil energy is high, however, as fossil fuels decrease, green energy has gradually become the trend. Hydrogen is a potential clean energy that can replace fossil fuels [1,2]. As hydrogen-oxygen fuel cells have risen rapidly in recent years, many scholars have concentrated on hydrogen storage. There are six main classes of hydrogen storage techniques including compression hydrogen storage, liquefaction hydrogen storage, metal hydrogen storage, chemical hydrogen storage, recombination hydrogen storage, and carbon nanotubes [3]. In comparison to other hydrogen storage techniques, the chemical hydrogen storage technique is characterized by high volume energy density and high weight energy density. The hydrogen production rate can be adjusted using high conversion efficiency catalysts [4]. Sarkar et al. [5] found that the chemical hydrogen storage had better hydrogen production than liquefaction hydrogen storage and compression hydrogen storage. In chemical hydrogen storage, the $\mathrm{NaBH}_{4}$ is highly attractive because its hydrogen content is as high as $10.8 \mathrm{wt} \%$, and is characterized by inflammability, stabilization in alkaline solution, controllable hydrolytic reaction, renewability, and environmental friendliness [6]. Table 1 shows the hydrogen 
mass and density in the catalyst hydrolytic hydrogen production reaction. It can be seen that the $\mathrm{NaBH}_{4}$ is less than $\mathrm{LiBH}_{4}$, but its byproduct is relatively simple [7]. With the appropriate catalyst, $\mathrm{NaBH}_{4}$ is converted into hydrogen and $\mathrm{NaBO}_{2}$. The equation is expressed as follows [8]:

$$
\mathrm{NaBH}_{4}+2 \mathrm{H}_{2} \mathrm{O} \stackrel{\text { catalyst }}{\rightarrow} 4 \mathrm{H}_{2}+\mathrm{NaBO}_{2}+217 \mathrm{~kJ} / \mathrm{mol}
$$

Table 1. Candidate hydride reactions and hydrogen storage properties [7].

\begin{tabular}{|c|c|c|c|}
\hline Hydride and Reaction & Fraction $\mathbf{H}$ & $\begin{array}{c}\mathrm{H}_{2} \text { Specific Mass } \\
\left(\mathrm{kg} \mathrm{H}_{2} / \mathrm{kg}\right)\end{array}$ & $\begin{array}{c}\mathrm{H}_{2} \text { Density } \\
\left(\mathrm{kg} \mathrm{H}_{2} / \mathrm{L}\right)\end{array}$ \\
\hline $\mathrm{LiH}+\mathrm{H}_{2} \mathrm{O} \rightarrow \mathrm{LiOH}+\mathrm{H}_{2}$ & 0.126 & 0.252 & 0.122 \\
\hline $\mathrm{NaH}+\mathrm{H}_{2} \mathrm{O} \rightarrow \mathrm{NaOH}+\mathrm{H}_{2}$ & 0.042 & 0.083 & 0.106 \\
\hline $\mathrm{CaH}_{2}+2 \mathrm{H}_{2} \mathrm{O} \rightarrow \mathrm{Ca}(\mathrm{OH})_{2}+2 \mathrm{H}_{2}$ & 0.048 & 0.095 & 0.121 \\
\hline $\mathrm{MgH}_{2} \rightarrow \mathrm{Mg}+\mathrm{H}_{2}$ & 0.076 & 0.076 & 0.110 \\
\hline $\mathrm{LiAlH}_{4}+\mathrm{H}_{2} \mathrm{O} \rightarrow \mathrm{LiOH}+\mathrm{Al}+2.5 \mathrm{H}_{2}$ & 0.105 & 0.132 & 0.121 \\
\hline $\mathrm{TiH}_{2} \rightarrow \mathrm{Ti}+\mathrm{H}_{2}$ & 0.040 & 0.040 & 0.152 \\
\hline $\mathrm{LiBH}_{4}+\mathrm{H}_{2} \mathrm{O} \rightarrow \mathrm{LiOH}+\mathrm{HBO}_{2}+4 \mathrm{H}_{2}$ & 0.184 & 0.367 & 0.235 \\
\hline $\mathrm{NaBH}_{4}+2 \mathrm{H}_{2} \mathrm{O} \rightarrow \mathrm{NaBO}_{2}+4 \mathrm{H}_{2}$ & 0.105 & 0.211 & 0.226 \\
\hline $\begin{array}{l}\text { Millennium Cell 35\% Solution } \\
\mathrm{NaBH}_{4}+4 \mathrm{H}_{2} \mathrm{O} \rightarrow \mathrm{NaBO}_{2}+4 \mathrm{H}_{2}+2 \mathrm{H}_{2} \mathrm{O}\end{array}$ & & 0.077 & 0.077 \\
\hline
\end{tabular}

The hydrolytic hydrogen production reaction is divided into aqueous solution hydrolysis and vapor hydrolysis. Figure 1 [9] shows the proportional relationship between the operating temperature range and aqueous solution hydrolysis and vapor hydrolysis byproduct when $\mathrm{NaBH}_{4}$ is in the hydrolytic hydrogen production reaction.

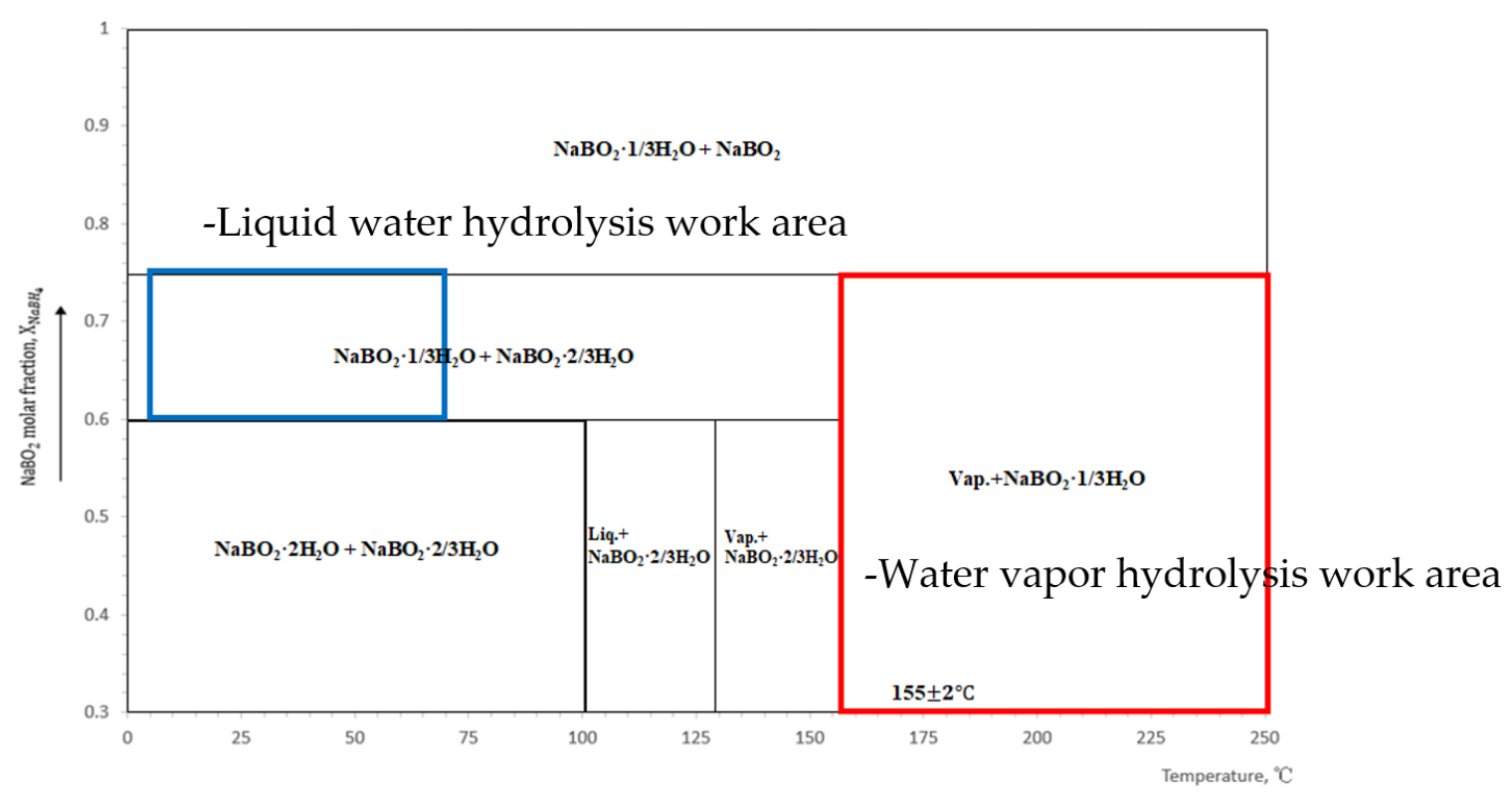

Figure 1. Proportional relation between the operating temperature range and byproduct of $\mathrm{NaBH}_{4}$ hydrolysis [9].

The $\mathrm{NaBH}_{4}$ hydrolytic hydrogen production reaction rate is correlated with the prepared aqueous $\mathrm{NaBH}_{4}$ solution and various metal catalysts used. Balba et al. [10] found that the $\mathrm{NaBH}_{4}$ concentration and temperature, hydrochloric acid, and acetic acid would change the hydrolytic hydrogen production reaction rate, where the hydrogen production rate increased with the acid concentration. Saka et al. [11] found that the phosphoric acid and $\mathrm{KBH}_{4}$ concentration and temperature influenced the hydrolytic hydrogen production reaction. The addition of $0.25 \mathrm{M}$ or $1 \mathrm{M}$ phosphoric acid could increase the hydrolytic 
hydrogen production reaction rate, with the total conversion $100 \%$ if the volume ratio to $\mathrm{KBH}_{4}$ was 1:1. Wang et al. [12] found that when the $\mathrm{NaOH}$ concentration in the blended $\mathrm{NaBH}_{4}$ and $\mathrm{NaOH}$ solution was changed, the hydrogen production rate was influenced, with $0.25 \mathrm{M} \mathrm{NaOH}$ having the best hydrogen production rate.

Metal chlorides such as $\mathrm{Fe}, \mathrm{Co}, \mathrm{Ni}, \mathrm{Ru}, \mathrm{Rh}$, and $\mathrm{Pd}$ are usually used in metal catalysts. The aqueous solution of some metal chlorides reduces the hydrolytic hydrogen production reaction rate [13]. Ke et al. [14] found that when the CoeB catalyst was modified by Mo, the hydrolytic hydrogen production reaction rate was $4200 \mathrm{~mL} / \mathrm{min}$, and indicated that the $\mathrm{NaBH}_{4}$ content adsorbed on the catalyst surface influenced the hydrolytic hydrogen production reaction rate. Vinokuov et al. [15] used hallo site nanotubes as the carrier, carrying metal catalyst $\mathrm{Co}^{2+}$ as the catalyst for hydrolytic hydrogen production reaction, where the best $\mathrm{Co}^{2+}$ concentration was $16 \mathrm{wt} \%$, and the maximum hydrogen production rate was $3 \mathrm{~L} / \mathrm{min} \mathrm{g}$ cat. Ye et al. [16] found that the $\mathrm{Co}^{2+}$ catalyst was carried by $\alpha-\mathrm{Al}_{2} \mathrm{O}_{3}$, due to the special structure, and the $\mathrm{Co} / \beta-\alpha-\mathrm{Al}_{2} \mathrm{O}_{3}$ containing $9 \%$ catalyst by weight at ambient temperature of $303 \mathrm{~K}$ could obtain the $\mathrm{HG}$ rate of $220 \mathrm{~mL} / \mathrm{min}-1 \mathrm{~g}-1$ catalyst and about $100 \%$ hydrogen production rate.

Furthermore, the aforesaid aqueous solution hydrolysis for $\mathrm{NaBH}_{4}$ hydrolytic hydrogen production reaction, using water vapor and $\mathrm{NaBH}_{4}$ for hydrogen production reaction is another method. Kong et al. [17] found that using liquid water for hydrogen production could obtain quantitative hydrogen production, but the hydrogen production rate was beyond their control. They used water vapor and limited the air input to react with hydride to control the hydrogen production rate. Marrero-Alfonso et al. [18] used vapor for the hydrolytic reaction, where the hydrogen production rate could reach $80 \%$ of the theoretical value without a catalyst. If acetic acid was applied, the time could be shortened, and the hydrogen production rate was 95\%. R Aiello et al. [19] found that in the vapor hydrolysis hydrogen production process, the temperature and flow velocity could influence the reaction process, but the main influencing factor was the vapor temperature.

In terms of observations on byproducts, Beaird et al. [20] found that Equation (2) was formed through gradual dehydration; if the temperature rose from $249^{\circ} \mathrm{C}$ to $280{ }^{\circ} \mathrm{C}$, solidification formed, expressed as Equation (3).

$$
\begin{aligned}
& 3 \mathrm{NaB}(\mathrm{OH})_{4} \stackrel{83^{\circ} \mathrm{C} \text { to } 155^{\circ} \mathrm{C}}{\rightarrow} \mathrm{Na}_{3}\left[\mathrm{~B}_{3} \mathrm{O}_{5}(\mathrm{OH})_{2}\right]+5 \mathrm{H}_{2} \mathrm{O} \\
& \mathrm{Na}_{3}\left[\mathrm{~B}_{3} \mathrm{O}_{5}(\mathrm{OH})_{2}\right] \stackrel{249^{\circ} \mathrm{C} \text { to } 280^{\circ} \mathrm{C}}{\rightarrow} \mathrm{Na}_{3} \mathrm{~B}_{3} \mathrm{O}_{6}+\mathrm{H}_{2} \mathrm{O}
\end{aligned}
$$

Marrero-Alfonso et al. [21] found when the primary product $\mathrm{NaBO}_{2}$ of vapor hydrolysis was dried at $350{ }^{\circ} \mathrm{C}$, anhydrous metaborate of $\mathrm{NaBO}_{2} \cdot 2 \mathrm{H}_{2} \mathrm{O}$ was formed, and the anhydrous metaborate of $\mathrm{NaBO}_{2} \cdot 4 \mathrm{H}_{2} \mathrm{O}$ was formed at $400{ }^{\circ} \mathrm{C}$.

To increase the hydrogen production in systems, this paper refers to the process designs and production methods proposed in previous studies. The two hydrogen production tanks in this paper will carry different catalysts. Baytar et al. [22] used the $\mathrm{Co}-\mathrm{Cu}-\mathrm{B} / \mathrm{Al}_{2} \mathrm{O}_{3}$ synthesized by $\mathrm{Co}-\mathrm{Cu}-\mathrm{B}$ and chemical impregnation as the catalyst for $\mathrm{NaBH}_{4}$ hydrolytic hydrogen production. The experimental results showed that the hydrogen production rate was $2519 \mathrm{~mL} / \mathrm{min} \mathrm{g}$ when $\mathrm{Co}-\mathrm{Cu}-\mathrm{B}$ was used as the catalyst while the hydrogen production rate of $\mathrm{Co}-\mathrm{Cu}-\mathrm{B} / \mathrm{Al}_{2} \mathrm{O}_{3}$ as the catalyst was $8962 \mathrm{~mL} / \mathrm{min}$ g, therefore, $\mathrm{Co}-\mathrm{Cu}-$ $\mathrm{B} / \mathrm{Al}_{2} \mathrm{O}_{3}$ as the catalyst had better efficiency. Kyunghwan et al. [23] used $\gamma-\mathrm{Al}_{2} \mathrm{O}_{3}$ as the carrier, immersed in $\mathrm{CoCl}_{2}$ solution carrying the Co catalyst, and baked at $350{ }^{\circ} \mathrm{C}$ for $3 \mathrm{~h}$ and reduced to make the catalyst $\mathrm{Co} / \mathrm{Al}_{2} \mathrm{O}_{3}$, which reacted with the $\mathrm{NaBH}_{4}$ solution fed in at $3 \mathrm{~mL} / \mathrm{min}$, and the hydrogen production efficiency was about $1071 \mathrm{~mL} / \mathrm{min}$. Kao et al. [24] used mechanical lapping equipment to grind $\mathrm{NaBH}_{4}$ powder and the Co catalyst for $30 \mathrm{~min}$, the powder particles were $5 \mu \mathrm{m}$, and dispersed uniformly. They indicated that the mixed powder was filled into the catalyst bed, and when the catalyst bed temperature increased, the hydrogen production rate was better. Wang et al. [25] mixed Co-B alloy and $\mathrm{NaBH}_{4}$ powder using mechanical lapping to enlarge the contact surface area in the hydrolytic hydrogen production reaction. The surface area was $202.4 \mathrm{~m} \mathrm{2/g}$, and the HGR 
for hydrolysis was $8.26 \mathrm{~L} / \mathrm{min}$ g. Wang et al. [26] performed ball milling of $\mathrm{NaBH}_{4}$ and $\mathrm{ZnCl}_{2}$ at $250 \mathrm{rpm}$ in a ball/powder ratio of 20:1 for 0.5 10 h, and performed hydrolytic hydrogen production, where the best hydrogen production was $1933 \mathrm{~mL} / \mathrm{g}$ when the ball milling time was $2 \mathrm{~h}$. According to the references, the $\mathrm{Co}^{2+} / \mathrm{Al}_{2} \mathrm{O}_{3}$ catalyst is used in the primary hydrogen production tank, and the $\mathrm{NaBH} 4+$ Co catalyst is used in the secondary hydrogen production tank.

\section{Results}

2.1. Comparison of $\mathrm{Co}^{2+} / \mathrm{Al}_{2} \mathrm{O}_{3}$ Catalyst Chelate Concentrations at Normal Temperature of $25^{\circ} \mathrm{C}$

The hydrogen productions of $10 \mathrm{wt} \%$ to $50 \mathrm{wt} \%$ catalysts were compared. The catalyst was placed in the primary hydrogen production tank, and $1.5 \mathrm{~g} 10 \mathrm{wt} \% \mathrm{NaBH}_{4}+1 \mathrm{wt} \%$ $\mathrm{NaOH}$ aqueous solution was injected into the primary hydrogen production tank. The hydrogen production rates from the catalyst bed at a normal temperature of $25^{\circ} \mathrm{C}$ were compared. According to the experiment, the $45 \mathrm{wt} \%$ catalyst had the best hydrogen production rate, as shown in Figure 2. The hydrogen production of the $45 \mathrm{wt} \%$ catalyst was $2.01 \mathrm{~L}$ (Liter), and Figure 2 shows that the $45 \mathrm{wt} \%$ catalyst had a better chelation degree.

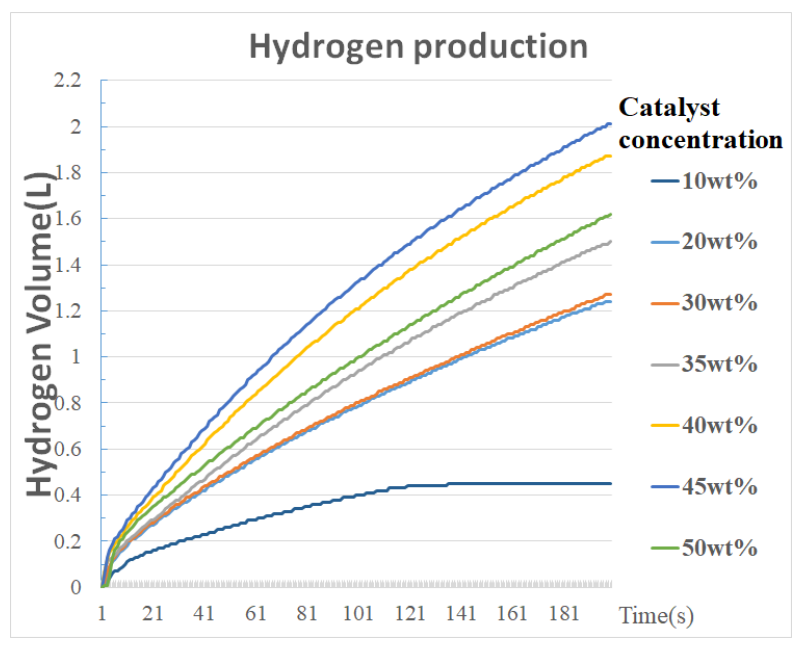

Figure 2. Comparison of the hydrogen production rates of the $\mathrm{Co}^{2+} / \mathrm{Al}_{2} \mathrm{O}_{3}$ catalyst chelate concentrations at a normal temperature of $25^{\circ} \mathrm{C}$.

\subsection{Comparison of Hydrogen Production Rates of $45 \mathrm{wt} \% \mathrm{Co}^{2+} / \mathrm{Al}_{2} \mathrm{O}_{3}$ Catalyst at Different Temperatures}

The $45 \mathrm{wt} \% \mathrm{Co}^{2+} / \mathrm{Al}_{2} \mathrm{O}_{3}$ catalyst was selected for the catalyst bed temperature of the primary hydrogen production tank for testing. The temperature range was $25^{\circ} \mathrm{C}$ to $70{ }^{\circ} \mathrm{C}$ for the hydrolytic hydrogen production test, and $1.5 \mathrm{~g} 10 \mathrm{wt} \% . \mathrm{NaBH}_{4}+1 \mathrm{wt} \%$ $\mathrm{NaOH}$ aqueous solution was injected into the primary hydrogen production tank. The experimental results showed that the optimum hydrogen production was $4.71 \mathrm{~L}$ when the catalyst bed temperature of primary hydrogen production tank was $55^{\circ} \mathrm{C}$, as shown in Figure 3. 


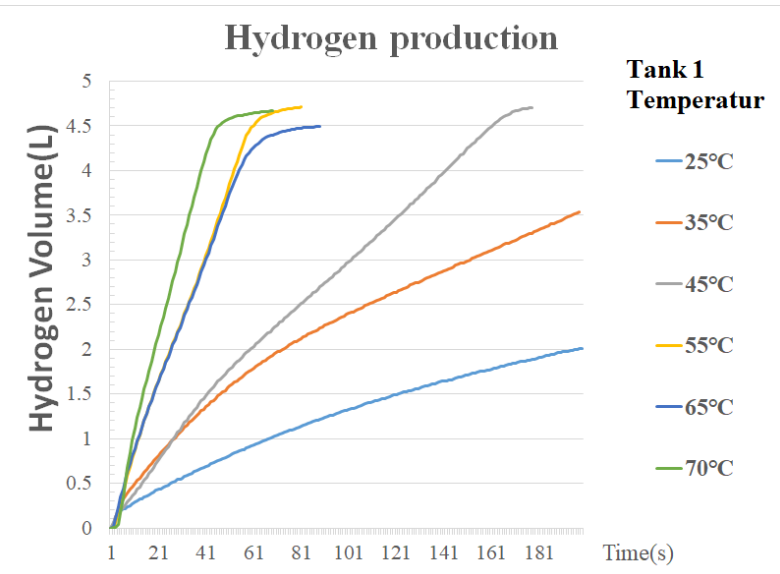

Figure 3. Comparison of the hydrogen production rates of the $45 \mathrm{wt} \% \mathrm{Co}^{2+} / \mathrm{Al}_{2} \mathrm{O}_{3}$ catalyst at different temperatures of catalyst bed of the primary hydrogen production tank.

\subsection{Comparison of Ball Milling Hydrogen Production Rates of $\mathrm{NaBH}_{4}+\mathrm{Co}$ in Different Ratios}

The secondary hydrogen production tank carries the $\mathrm{NaBH}_{4}+\mathrm{Co}^{2+}$ catalyst. Ball milling was performed with steel ball size ratio of 1:4 and catalyst ratio of 9:1 to 6:4 for $2 \mathrm{~h}$. The $45 \mathrm{wt} \%$ catalyst was placed in the primary hydrogen production tank. The primary catalyst bed temperature was $55^{\circ} \mathrm{C}$, and the secondary catalyst bed temperature was $80^{\circ} \mathrm{C}$, and $5.56 \mathrm{~g} 10 \mathrm{wt} \% \mathrm{NaBH}_{4}+1 \mathrm{wt} \% \mathrm{NaOH}$ aqueous solution was injected into the primary hydrogen production tank for the hydrogen production test. According to the experimental results, the hydrogen production of the $\mathrm{NaBH}_{4}+\mathrm{Co}^{2+}$ catalyst in the ratio of 7:3 was 17.4 L, better than the $\mathrm{NaBH}_{4}+\mathrm{Co}^{2+}$ catalyst in the other ratios, as shown in Figure 4. The hydrogen production of the secondary hydrogen production tank with the molecular sieve was $14.03 \mathrm{~L}$.

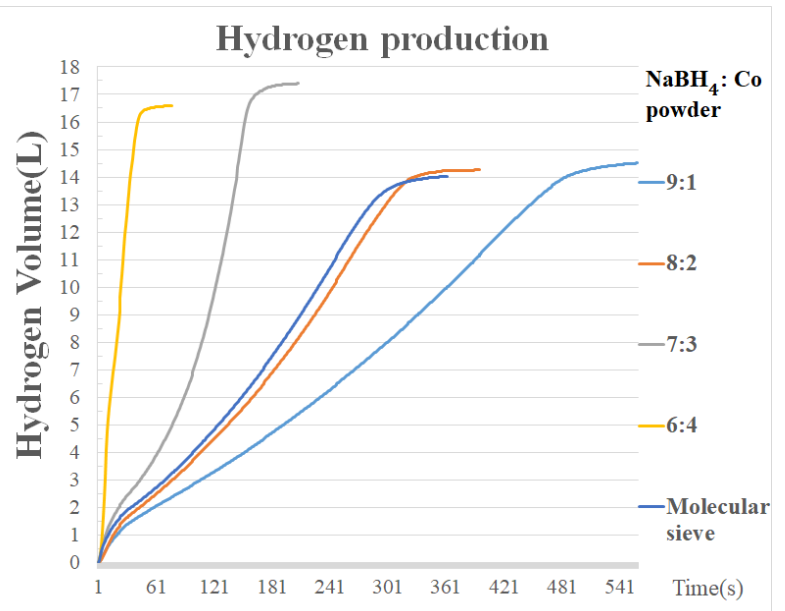

Figure 4. Comparison of the ball milling hydrogen production rates of $\mathrm{NaBH}_{4}+\mathrm{Co}^{2+}$ in different ratios.

\subsection{Comparison of Hydrogen Production Rates of Ball Milling Steel Ball in Different Ratios}

Different steel ball size ratios can influence the powder milling result. The steel ball size ratio changed from 1:1 to 1:6 to mill $\mathrm{NaBH}_{4}+\mathrm{Co}^{2+}$ catalyst powder in the ratio of 7:3 for $2 \mathrm{~h}$. The hydrogen production was tested under identical conditions for the primary hydrogen production tank and secondary hydrogen production tank in Section 2.3. According to the experiment, the hydrogen production of the milling steel ball size ratio of 1:4 for $2 \mathrm{~h}$ was better than the other steel ball size ratios, as shown in Figure 5. 


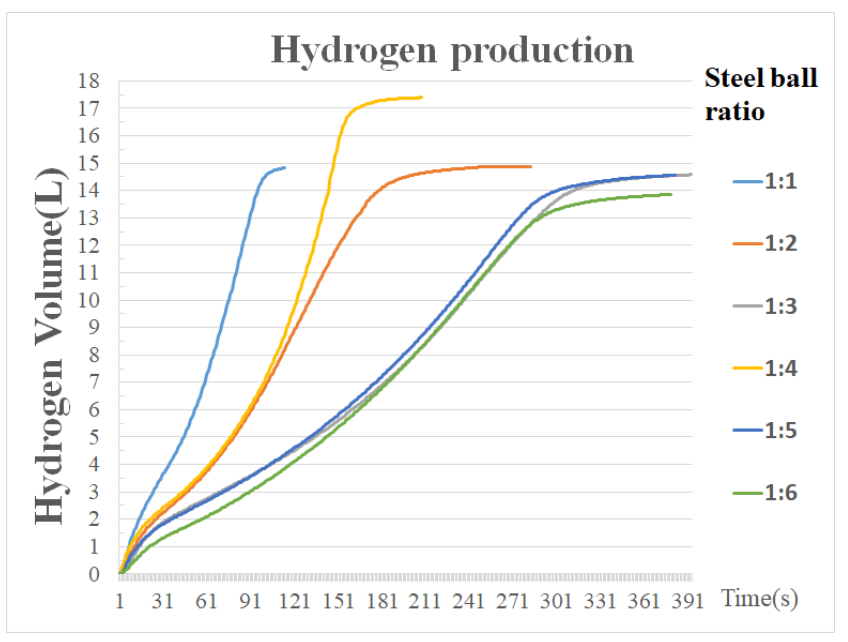

Figure 5. Comparison of hydrogen production rates of ball milling steel ball in different ratios.

\subsection{Comparison of Hydrogen Production Rates of Different Ball Milling Times}

The length of ball milling time influences the powder particle size, so the ball milling time was set as $1 \mathrm{~h}$ to $4 \mathrm{~h}$ for ball milling in this paper, and the hydrogen production was tested under the experimental conditions in Section 2.4. The experimental results showed that the hydrogen production of $2 \mathrm{~h}$ ball milling was $18.38 \mathrm{~L}$, better than the hydrogen production of the other milling times, as shown in Figure 6.

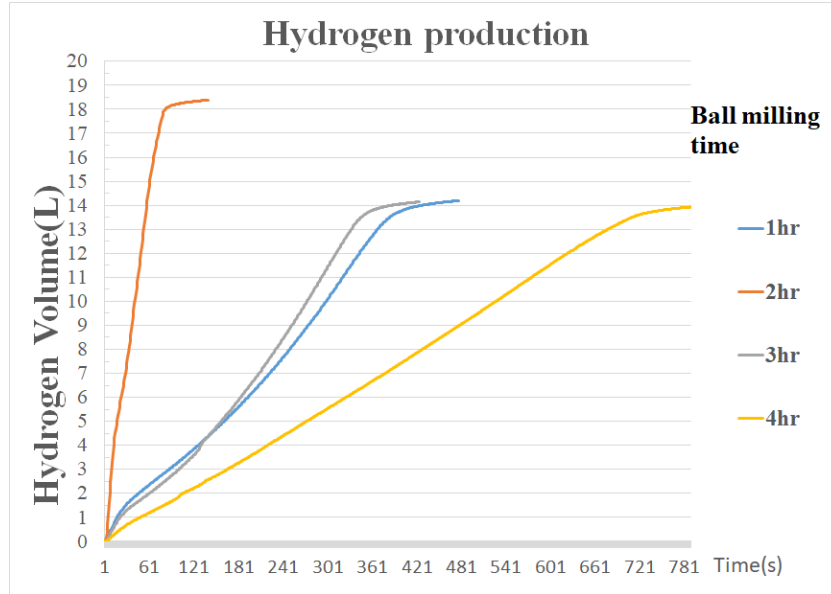

Figure 6. Comparison of hydrogen production rates of different ball milling times.

2.6. Comparison of Hydrogen Production Rates at Different Temperatures of Catalyst Bed of Secondary Hydrogen Production Tank

The catalyst bed temperature of the secondary hydrogen production tank maintains the water vapor entrained in the hydrolytic hydrogen production reaction of primary hydrogen production tank. The catalyst bed temperature of the secondary hydrogen production tank was set as $80^{\circ} \mathrm{C}$ to $100{ }^{\circ} \mathrm{C}$ for the hydrogen production test, and the other conditions were identical with the experimental conditions in Section 2.5. According to the experimental results, the hydrogen production of the secondary hydrogen production tank catalyst bed at $80^{\circ} \mathrm{C}$ was better than the other temperatures, as shown in Figure 7 . 


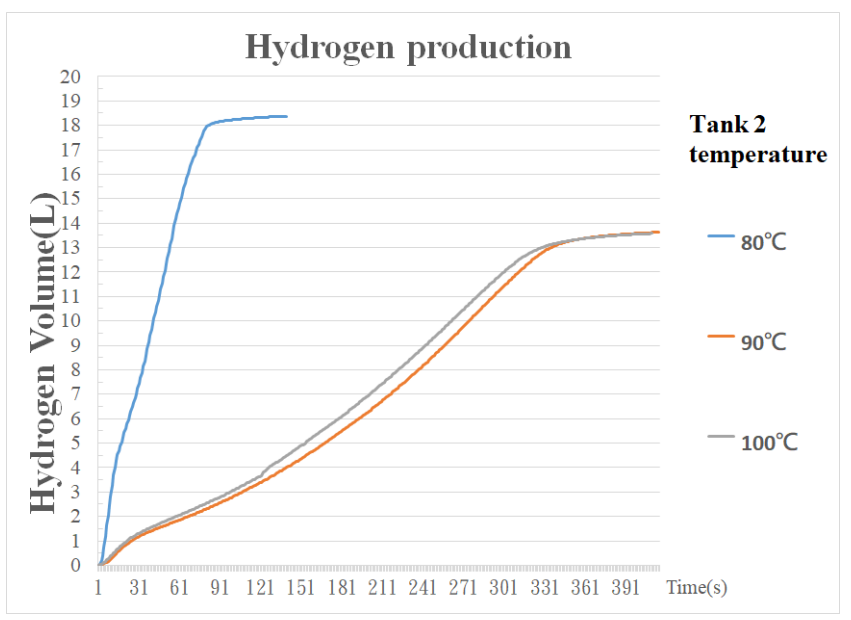

Figure 7. Comparison of hydrogen production rates at different catalyst bed temperatures for the secondary hydrogen production tank.

\section{Discussion}

The $\mathrm{Co}^{2+} / \mathrm{Al}_{2} \mathrm{O}_{3}$ catalyst and $\mathrm{NaBH}_{4}+\mathrm{Co}^{2+}$ catalyst were loaded into two hydrogen production tanks, respectively, and the $\mathrm{NaBH}_{4}$ hydrolytic hydrogen production reaction process was performed under different conditions. The experimental aqueous solution concentration condition was fixed at $10 \mathrm{wt} \% . \mathrm{NaBH}_{4}+1 \mathrm{wt} \% \mathrm{NaOH}$ was injected into the hydrogen production tank to react with the catalyst to generate hydrogen. According to the hydrogen production efficiency experimental results, in the primary hydrogen production tank, the $\mathrm{Co}^{2+} / \mathrm{Al}_{2} \mathrm{O}_{3}$ catalyst at $45 \mathrm{wt} \%$ concentration was used. The primary hydrogen production tank catalyst bed was heated to $55{ }^{\circ} \mathrm{C}$ with the secondary hydrogen production tank process. $\mathrm{NaBH}_{4}+\mathrm{Co}^{2+}$ catalyst ball milling in the ratio of 7:3 was performed using the steel ball size ratio of 1:4 for $2 \mathrm{~h}$. The secondary hydrogen production tank catalyst bed was heated to $80^{\circ} \mathrm{C}$. The maximum hydrogen production of the overall experimental system was $18.38 \mathrm{~L}$. In comparison to the $14.03 \mathrm{~L}$ hydrogen production without catalyst inside the secondary hydrogen production tank, the hydrogen production was increased by $4.35 \mathrm{~L}$. It was found in the experimental process that the byproduct $\mathrm{NaBO}_{2}$ in $\mathrm{NaBH}_{4}$ hydrolytic hydrogen production reaction could be dried and solidified by heating the secondary hydrogen production tank. The $\mathrm{NH}_{3}$ can be dissolved in a pure water filter flask, and a molecular sieve filter flask can be used for prevention, so it can be removed to reduce partial space and cost.

\section{Materials and Methods}

\section{1. $\mathrm{Co}^{2+} / \mathrm{Al}_{2} \mathrm{O}_{3}$ Catalyst Process}

This study prepared 10 50 wt $\%$ samples of the $\mathrm{Co}^{2+} / \mathrm{Al}_{2} \mathrm{O}_{3}$ catalyst. The $\gamma-\mathrm{Al}_{2} \mathrm{O}_{3}$ was cleaned with ionized water in advance, and baked in a vacuum drying oven at $120{ }^{\circ} \mathrm{C}$ for $4 \mathrm{~h}$ to remove moisture content. The dried $\gamma-\mathrm{Al}_{2} \mathrm{O}_{3}$ was soaked in $10 \sim 50 \mathrm{wt} \% \mathrm{CoCl}_{2}$ solution for $12 \mathrm{~h}$, so that the $\mathrm{Co}^{2+}$ in the solution fully adhered to $\gamma-\mathrm{Al}_{2} \mathrm{O}_{3}$. Afterward, the $\mathrm{CoCl}_{2}$ solution was filtered out, and the soaked $\gamma-\mathrm{Al}_{2} \mathrm{O}_{3}$ was baked in the vacuum drying oven at $120^{\circ} \mathrm{C}$ for $6 \mathrm{~h}$. The catalyst $\mathrm{Co}^{2+} / \mathrm{Al}_{2} \mathrm{O}_{3}$ was prepared, as shown in Figure 8 .

The bearing of metal $\mathrm{Co}^{2+}$ of the prepared $\mathrm{Co}^{2+} / \mathrm{Al}_{2} \mathrm{O}_{3}$ catalyst was observed through SEM. Figure 9 shows the preliminary sting and situation, while Figure 10 used the mapping material analysis system to analyze the distribution of cobalt. From this, it can be judged that the sting and effect of $45 \mathrm{wt} \%$ were better than the others. 


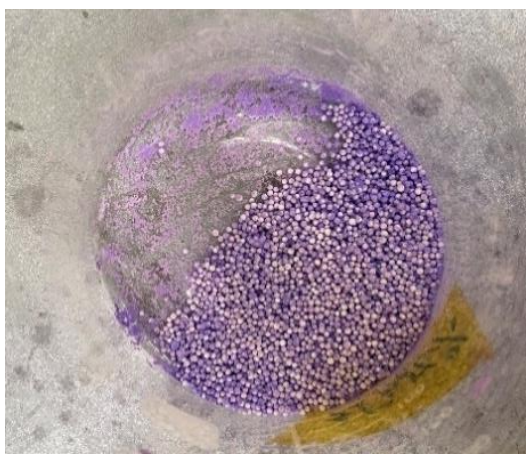

Figure 8. Complete diagram of the prepared $\mathrm{Co}^{2+} / \mathrm{Al}_{2} \mathrm{O}_{3}$ catalyst.

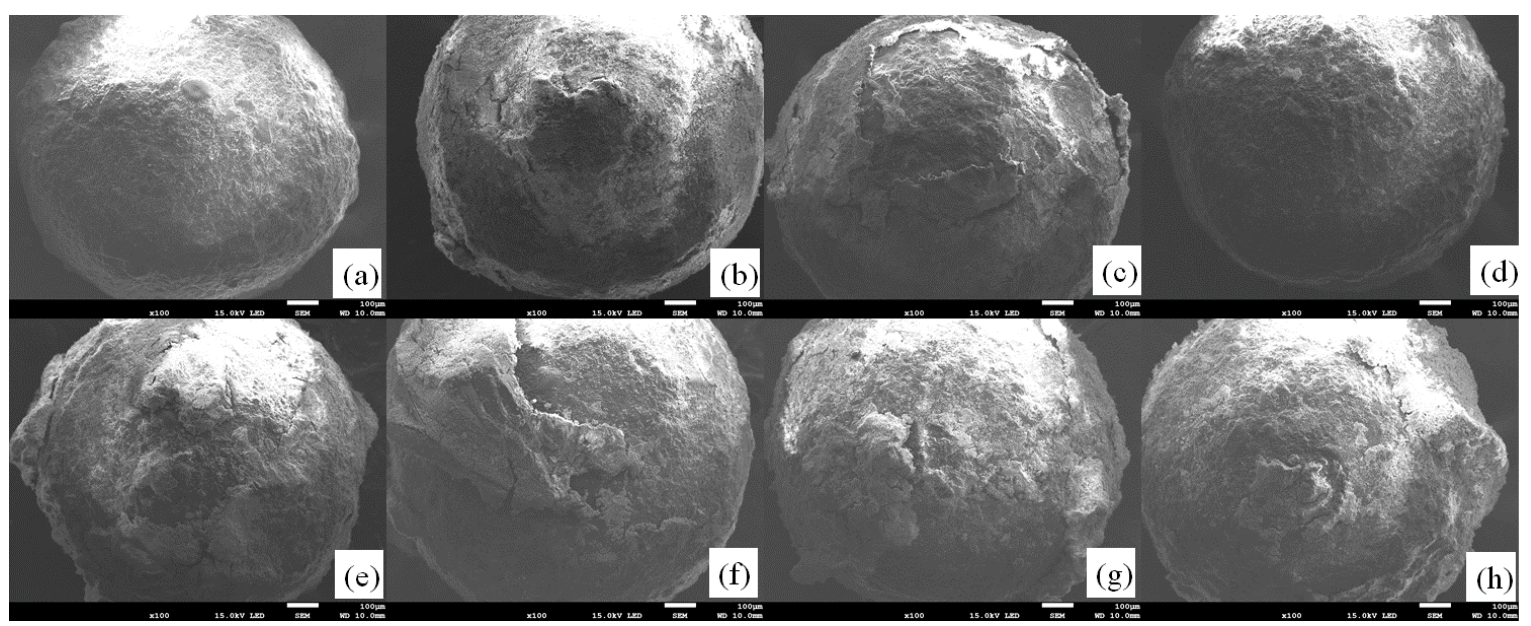

Figure 9. SEM images of the $\mathrm{Co}^{2+} / \mathrm{Al}_{2} \mathrm{O}_{3}$ catalyst at various concentrations. (a) Original $\gamma-\mathrm{Al}_{2} \mathrm{O}_{3} ;(\mathbf{b}) 10 \mathrm{wt} \% \mathrm{Co}^{2+} / \mathrm{Al}_{2} \mathrm{O}_{3}$; (c) $20 \mathrm{wt} \% \mathrm{Co}^{2+} / \mathrm{Al}_{2} \mathrm{O}_{3} ;$ (d) $30 \mathrm{wt} \% \mathrm{Co}^{2+} / \mathrm{Al}_{2} \mathrm{O}_{3} ;$ (e) $35 \mathrm{wt} \% \mathrm{Co}^{2+} / \mathrm{Al}_{2} \mathrm{O}_{3} ;$ (f) $40 \mathrm{wt} \% \mathrm{Co}^{2+} / \mathrm{Al}_{2} \mathrm{O}_{3} ;\left(\right.$ g) $45 \mathrm{wt} \% \mathrm{Co}^{2+} / \mathrm{Al}_{2} \mathrm{O}_{3}$; (h) $50 \mathrm{wt} \% \mathrm{Co}^{2+} / \mathrm{Al}_{2} \mathrm{O}_{3}$.
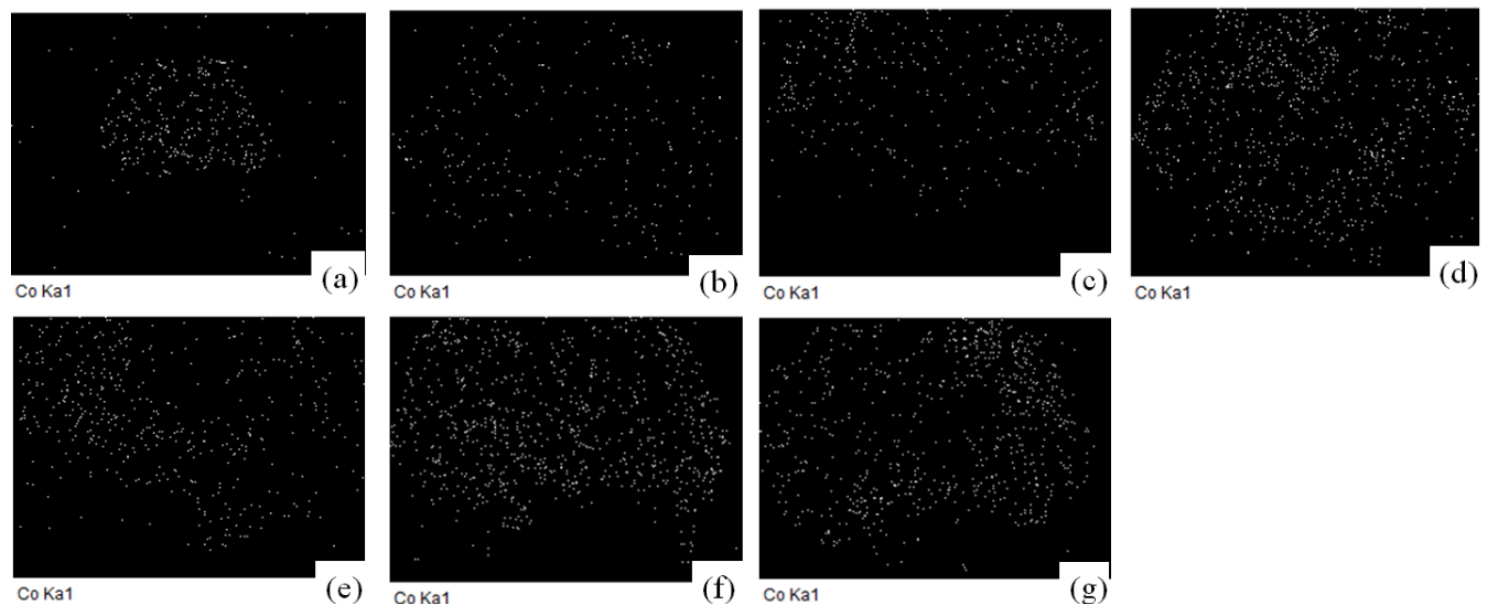

Figure 10. Mapping cobalt distribution map. (a) $10 \mathrm{wt} \% \mathrm{Co}^{2+} / \mathrm{Al}_{2} \mathrm{O}_{3} ;$ (b) $20 \mathrm{wt} \% \mathrm{Co}^{2+} / \mathrm{Al}_{2} \mathrm{O}_{3}$; (c) $30 \mathrm{wt}^{\mathrm{O}} \% \mathrm{Co}^{2+} / \mathrm{Al}_{2} \mathrm{O}_{3}$; (d) $35 \mathrm{wt} \% \mathrm{Co}^{2+} / \mathrm{Al}_{2} \mathrm{O}_{3} ;$ (e) $40 \mathrm{wt} \% \mathrm{Co}^{2+} / \mathrm{Al}_{2} \mathrm{O}_{3} ;$ (f) $45 \mathrm{wt} \% \mathrm{Co}^{2+} / \mathrm{Al}_{2} \mathrm{O}_{3} ;$ (g) $50 \mathrm{wt} \% \mathrm{Co}^{2+} / \mathrm{Al}_{2} \mathrm{O}_{3}$.

Take 10 pellets out from each sample and measure the weight. The average value of 3 5 groups were measured before observation. Table 2 shows that the value display at $45 \mathrm{wt} \%$ was the best. 
Table 2. Each concentration of $\mathrm{Co}^{2+} / \mathrm{Al}_{2} \mathrm{O}_{3}$ takes the weight of 10 particles.

\begin{tabular}{lcccccc}
\hline & No. $\mathbf{1}$ & No. $\mathbf{2}$ & No. $\mathbf{3}$ & No. $\mathbf{4}$ & No. 5 & Average \\
\hline original & 0.02 & 0.019 & 0.021 & 0.022 & 0.019 & 0.0202 \\
$10 \mathrm{wt} \%$ & 0.022 & 0.022 & 0.022 & 0.022 & 0.025 & 0.0226 \\
$20 \mathrm{wt} \%$ & 0.023 & 0.02 & 0.021 & 0.022 & 0.022 & 0.0216 \\
$30 \mathrm{wt} \%$ & 0.021 & 0.024 & 0.023 & 0.024 & 0.023 & 0.023 \\
$35 \mathrm{wt} \%$ & 0.021 & 0.021 & 0.023 & 0.021 & 0.023 & 0.0218 \\
$40 \mathrm{wt} \%$ & 0.021 & 0.021 & 0.022 & 0.023 & 0.025 & 0.0224 \\
$45 \mathrm{wt} \%$ & 0.025 & 0.025 & 0.022 & 0.024 & 0.024 & 0.024 \\
$50 \mathrm{wt} \%$ & 0.023 & 0.021 & 0.022 & 0.022 & 0.024 & 0.0224 \\
\hline (Unit: grams) & & & & & &
\end{tabular}

\section{2. $\mathrm{NaBH}_{4}+\mathrm{Co}^{2+}$ Catalyst Process}

The $\mathrm{NaBH}_{4}, \mathrm{Co}^{2+}$, and steel balls at different ratios were used for ball milling. The ball milling steel ball sizes were $4.75 \mathrm{~mm}$ and $3 \mathrm{~mm}$. The $\mathrm{NaBH}_{4}-\mathrm{Co}^{2+}$ ratio was 9:1 to 6:4, and the steel ball size ratio of 1:4 was used for 2-h ball milling. The steel ball size ratio was changed from 1:1 to 1:6 for 2-h ball milling. Finally, the ball milling time was changed from $1 \mathrm{~h}$ to $4 \mathrm{~h}$ for testing. The prepared catalyst is shown in Figure 11. Demirci et al. [27] observed the mixed $\mathrm{Co}^{2+}$ and $\mathrm{NaBH}_{4}$, and it was found that the $\mathrm{Co}-\mathrm{B}$ formed a thin film on the surface. This thin film crystallized into a black solid. It was proven that the milling color in Figure 11 is a normal phenomenon.

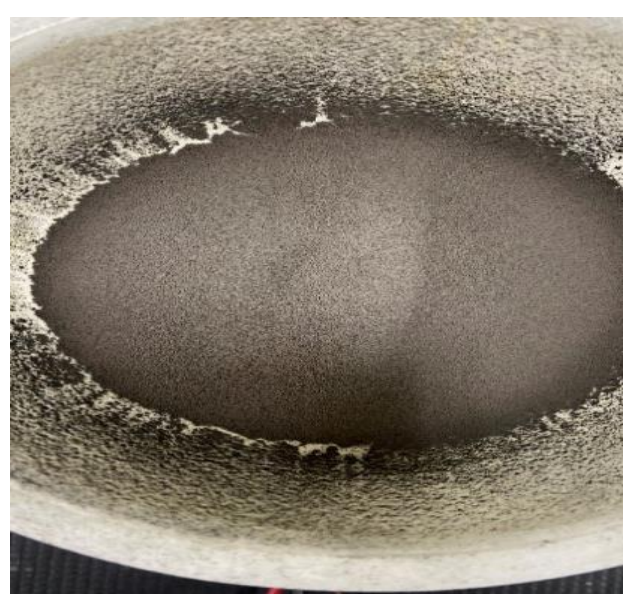

Figure 11. Schematic diagram of the $\mathrm{NaBH}_{4}+\mathrm{Co}^{2+}$ catalyst after ball milling.

The ball milling $\mathrm{NaBH}_{4}+\mathrm{Co}^{2+}$ catalyst in the changed steel ball size ratio was observed through SEM, as shown in Figure 12. The ball milling powder particles from the steel ball size ratio of 1:4 were better than the other ratios. The minimum powder particle size was $131 \mu \mathrm{m}$.

The $\mathrm{NaBH}_{4}+\mathrm{Co}^{2+}$ catalyst powder of different ball milling times was investigated by SEM. The ball milling particles became finer as the ball milling time increased, but the water vapor in the environment was adsorbed more rapidly, and was likely to induce agglomeration. The SEM image of $2 \mathrm{~h}$ of ball milling is shown in Figure 13. The powder particles were relatively even. 

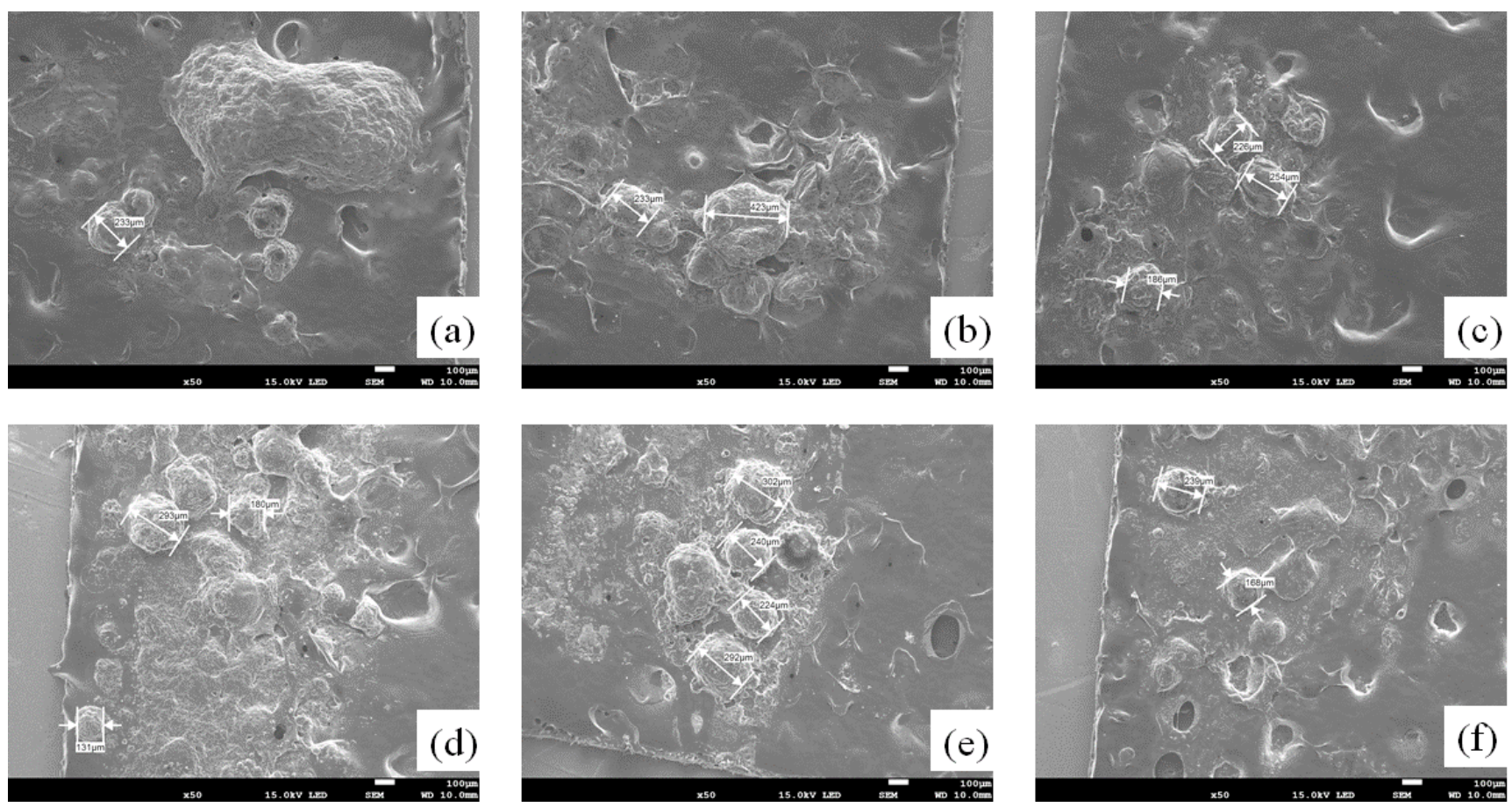

Figure 12. SEM images of different steel ball size ratios. (a) Ball milled powder with steel balls ratio 1:1; (b) ball milled powder with steel balls ratio 1:2; (c) ball milled powder with steel balls ratio 1:3; (d) ball milled powder with steel balls ratio 1:4; (e) ball milled powder with steel balls ratio 1:5; (f) ball milled powder with steel balls ratio 1:6.
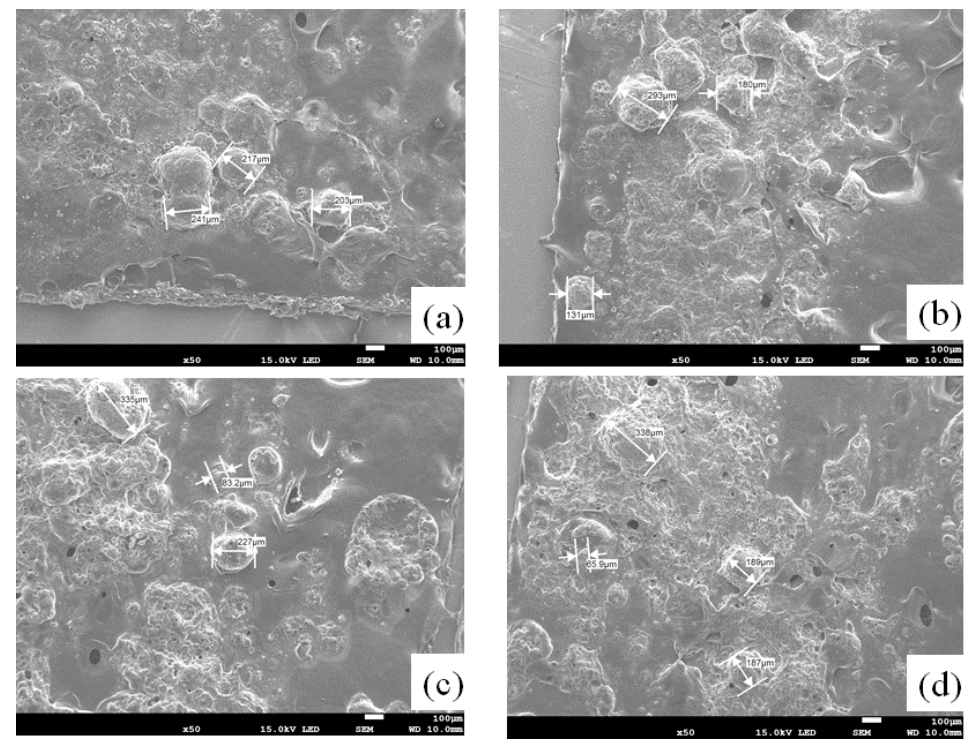

Figure 13. SEM images of different ball milling times. (a) Ball milled the powder for $1 \mathrm{~h}$ with a steel balls ratio of $1: 4 ;(\mathbf{b})$ ball milled the powder for $2 \mathrm{~h}$ with a steel balls ratio of $1: 4$; (c) ball milled the powder for $3 \mathrm{~h}$ with a steel balls ratio of 1:4; (d) ball milled the powder for $4 \mathrm{~h}$ with a steel balls ratio of $1: 4$.

\subsection{Experimental Setup}

\subsubsection{Hydrogen Production System}

The experimental setup is shown in Figure 14. The $\mathrm{Co}^{2+} / \mathrm{Al}_{2} \mathrm{O}_{3}$ catalyst was placed in the primary hydrogen production tank. The secondary hydrogen production tank was filled with the $\mathrm{NaBH}_{4}+\mathrm{Co}^{2+}$ catalyst. The $\mathrm{NaBH}_{4}+\mathrm{NaOH}$ solution was injected into the primary hydrogen production tank through the injection opening to produce 
hydrogen. The water vapor entrained in hydrogen reacted with $\mathrm{NaBH}_{4}+\mathrm{Co}^{2+}$ catalyst in the secondary hydrogen production tank, and the hydrogen volume was increased. It was then filtered using a pure water filter flask and a molecular sieve filter flask. Finally, the total hydrogen yield was read and recorded using a hydrogen flow meter. When the hydrogen flow meter reading was zero, the recording was stopped, and the experiment was finished.

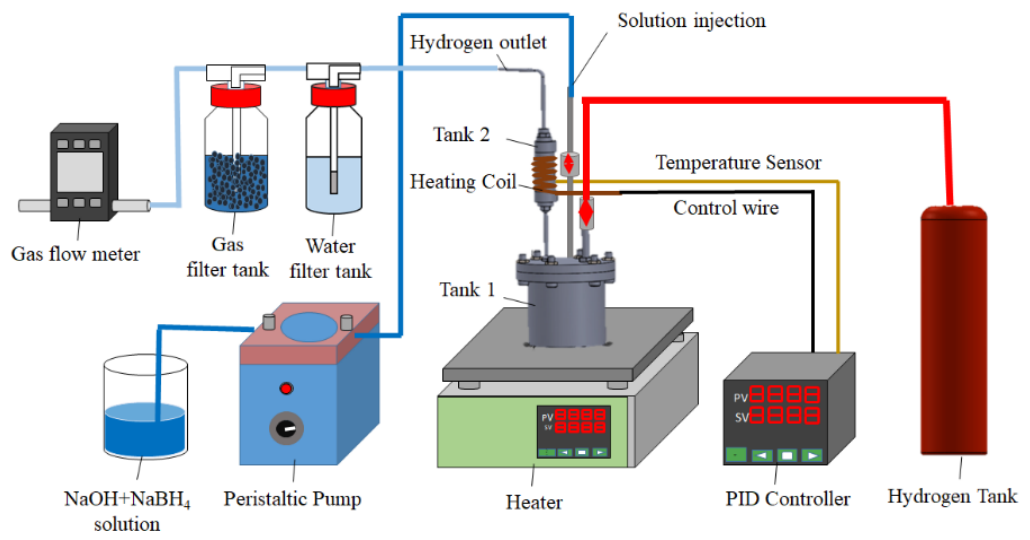

Figure 14. Schematic diagram of the experimental setup.

\subsubsection{Primary Hydrogen Production Tank}

The primary hydrogen production tank was the main hydrogen production chamber body. The catalyst bed was heated by the lower heater, and the $\mathrm{Co}^{2+} / \mathrm{Al}_{2} \mathrm{O}_{3}$ catalyst was placed in it. The $\mathrm{NaBH}_{4}$ solution was injected for hydrogen production reaction. Kim et al. [28] found that the $\mathrm{NaBH}_{4}$ and $\mathrm{NaOH}$ concentration and solution flow rate influenced the hydrogen production reaction. They used a pump to control the solution flow velocity, and the blended solution concentration of $20 \mathrm{wt} \% \mathrm{NaBH}_{4}+1 \mathrm{wt} \% \mathrm{NaOH}$ resulted in about $6 \mathrm{~L} / \mathrm{min}$ of hydrogen production at the optimum flow velocity of $17.5 \mathrm{~mL} / \mathrm{min}$. Amendola et al. [29] found the $\mathrm{NaBH}_{4}$ and $\mathrm{NaOH}$ blended solution concentration in the hydrogen production reaction. Figure 15 shows that the $10 \mathrm{wt} \% \mathrm{NaBH}_{4}+1 \mathrm{wt} \% \mathrm{NaOH}$ solution had a better hydrogen production rate. Afterward, the hydrogen in the hydrogen production reaction process entrained water vapor into the secondary hydrogen production tank, entering the back-end hydrogen production process. In J. L. Lai et al. [30], they used a sodium borohydride solution of $10 \mathrm{wt} \% \mathrm{NaBH}_{4}+1 \mathrm{wt} \% \mathrm{NaOH}$ and a $\mathrm{Co}^{2+} / \mathrm{Al}_{2} \mathrm{O}_{3}$ catalyst with a chelating concentration of $30 \mathrm{wt} \%$ to produce hydrogen at a catalyst bed temperature of $70{ }^{\circ} \mathrm{C}$. Although it had the highest hydrogen production rate at $5300 \mathrm{~mL} / \mathrm{min}$ $\mathrm{g}$ cat. The hydrogen production efficiency was only $82.92 \%$. However, in the hydrogen production efficiency test results, it is known that the $\mathrm{Co}^{2+} / \mathrm{Al}_{2} \mathrm{O}_{3}$ catalyst with a chelating concentration of $20 \mathrm{wt} \%$ can be produced at a catalyst bed temperature of $65^{\circ} \mathrm{C}$. The hydrogen efficiency was as high as $99.13 \%$. The experimental results confirmed that different $\mathrm{Co}^{2+} / \mathrm{Al}_{2} \mathrm{O}_{3}$ catalyst solution concentrations and catalyst bed temperatures all affected hydrogen production.

\subsubsection{Secondary Hydrogen Production Tank}

The $\mathrm{NaBH}_{4}+\mathrm{Co}^{2+}$ catalyst was loaded into the secondary hydrogen production tank. A heating coil and PID controller were provided outside to maintain the catalyst bed temperature. The tank was covered with fiberglass for warmth retention. The heat dissipation was mitigated, as shown in Figure 16. The purpose of heating is to maintain the water vapor entrained after hydrolytic hydrogen production reaction in the primary hydrogen production tank. Akkus et al. [31] indicated that hydrogen generation could be increased by performing the $\mathrm{NaBH}_{4}$ hydrolytic hydrogen production reaction in a high temperature catalyst bed and the reaction of byproducts was reduced to generate purified hydrogen. 


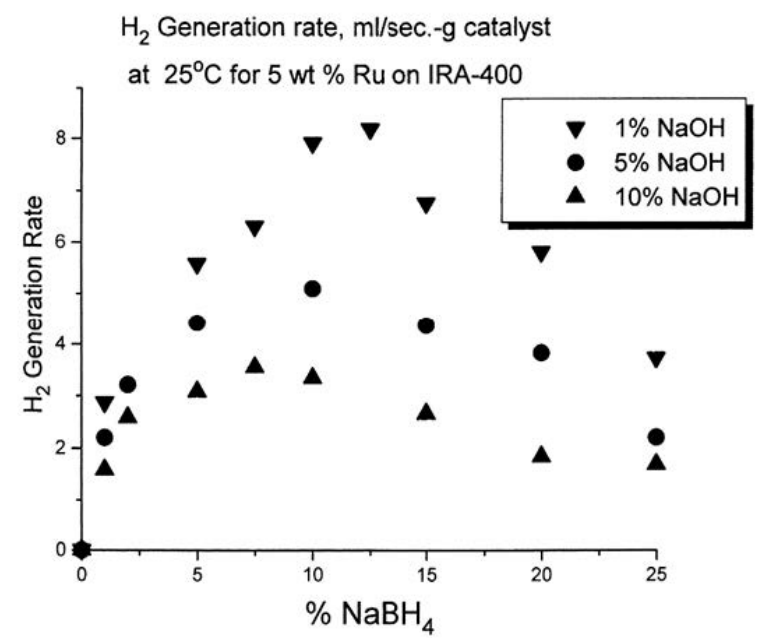

Figure 15. Effect of $\mathrm{NaOH}$ on $\mathrm{NaBH}_{4}$ hydrogen desorption rate.

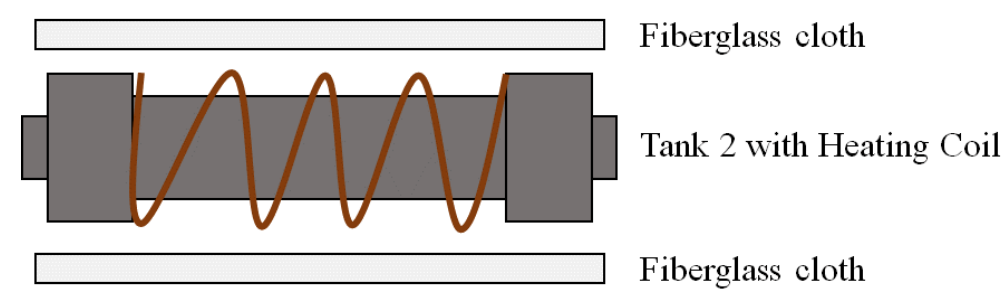

Figure 16. Secondary hydrogen production tank set-up diagram.

\subsubsection{Pure Water Filter Flask}

Aside from hydrogen, the $\mathrm{NaBH}_{4}$ hydrolytic hydrogen production reaction generates $\mathrm{NaBO}_{2}$ and a small amount of $\mathrm{NH}_{3}$. These alkaline byproducts are soluble in water, making the aqueous solution strongly alkaline. If the hydrogen carrying alkaline water enters the fuel cell system through reaction, the entrained material condenses as the temperature drops. Therefore, the hydrogen mass and the efficiency and fuel cell life are influenced. Therefore, a pure water filter flask was provided at the front end to filter the water soluble material in advance for prevention.

\subsubsection{Molecular Sieve Filter Flask}

Molecular sieves can purify dry air, hydrogen, oxygen, and nitrogen. The molecular sieve filter flask was arranged at the back end of a pure water filter flask to purify hydrogen, but also prevent the water vapor in the pure water filter flask from evaporating. The water vapor is absorbed to obtain more purified hydrogen.

Author Contributions: Conceptualization, J.-L.L. and Y.-D.K.; Data curation, J.-L.L., Y.-D.K. and P.J.Z.; Formal analysis, J.-L.L. and P.-J.Z.; Funding acquisition, Y.-D.K.; Investigation, J.-L.L., W.-J.L. and P.-J.Z.; Methodology, J.-L.L., Y.-D.K. and P.-J.Z.; Project administration, Y.-D.K.; Resources, Y.-D.K.; Supervision, W.-J.L. and Y.-D.K.; Writing—original draft, J.-L.L.; Writing—review \& editing, W.-J.L. and Y.-D.K. All authors have read and agreed to the published version of the manuscript.

Funding: This research was funded by the Ministry of Science and Technology, Taiwan (MOST 109-2221-E-167-006).

Data Availability Statement: Data sharing not applicable.

Acknowledgments: The authors acknowledge the financial support from the Ministry of Science and Technology, Taiwan.

Conflicts of Interest: The authors declare no conflicts of interest. 


\section{References}

1. Lund, H. Renewable energy strategies for sustainable development. Energy 2007, 32, 912-919. [CrossRef]

2. Nikolaidis, P.; Poullikkas, A. A comparative overview of hydrogen production processes. Renew. Sustain. Energy Rev. 2017, 67, 597-611. [CrossRef]

3. Mench, M.M. Fuel Cell Engines; John Wiley \& Sons Inc.: Hoboken, NJ, USA, 2008.

4. Sorensen, B. Hydrogen and Fuel Cells: Emerging Technologies and Applications; Elsevier Academic Press: Cambridge, MA, USA, 2005.

5. Sarkar, A.; Banerjee, R. Net energy analysis of hydrogen storage options. Int. J. Hydrogen Energy 2005, 30, 867-877. [CrossRef]

6. Kim, T. NaBH4 (sodium borohydride) hydrogen generator with a volume-exchange fuel tank for small unmanned aerial vehicles powered by a PEM (proton exchange membrane) fuel cell. Energy 2014, 69, 721-727. [CrossRef]

7. Klanchar, M.; Hughes, T.G.; Gruber, P. Attaining Doe Hydrogen Storage Goals with Chemical Hydrides, Senior Research Associate; Applied Research Laboratory, The Pennsylvania State University: State College, PA, USA, 2003.

8. Schlesinger, H.I.; Brown, H.C.; Brown, A.B.; Finholt, J.R.; Gilbreath, H.R.; Hockstra, E.K.; Hydo, E.K. Sodium Borohydride, Its Hydrolysis and its Use as a Reducing Agent and in the Generation of Hydrogen. J. Am. Chem. Soc. 1953, 75215.

9. Andrieux, J.; Laversenne, L.; Krol, O.; Chiriac, R.; Bouajila, Z.; Tenu, R.; Counioux, J.J.; Goutaudier, $\mathrm{C}$. Revision of the $\mathrm{NaBO}_{2}-\mathrm{H}_{2} \mathrm{O}$ phase diagram for optimized yield in the $\mathrm{H} 2$ generation through NaBH4 hydrolysis. Int. J. Hydrogen Energy 2012, 37, 5798-5810. [CrossRef]

10. Balbay, A.; Saka, C. The effect of the concentration of hydrochloric acid and acetic acid aqueous solution for fast hydrogen production from methanol solution of NaBH4. Int. J. Hydrogen Energy 2018, 43, 14265-14272. [CrossRef]

11. Saka, C.; Balbay, A. Fast and effective hydrogen production from ethanolysis and hydrolysis reactions of potassium borohy-dride using phosphoric acid. Int. J. Hydrogen Energy 2018, 43, 19976-19983. [CrossRef]

12. Wang, J.; Ke, D.; Li, Y.; Zhang, H.; Wang, C.; Zhao, X.; Yuan, Y.; Han, S. Efficient hydrolysis of alkaline sodium borohydride catalyzed by cobalt nanoparticles supported on three-dimensional graphene oxide. Mater. Res. Bull. 2017, 95, 204-210. [CrossRef]

13. Li, Z.; Li, H.; Wang, L.; Liu, T. Hydrogen generation from catalytic hydrolysis of sodium borohydride solution using supported amorphous alloy catalysts (Ni-Co-P/g- $\mathrm{Al}_{2} \mathrm{O}_{3}$ ). Int. J. Hydrogen Energy 2014, 39, 14935-14941. [CrossRef]

14. Ke, D.; Tao, Y.; Li, Y.; Zhao, X.; Zhang, L.; Wang, J.; Han, S. Kinetics study on hydrolytic dehydrogenation of alkaline sodium borohydride catalyzed by Mo-modified Co-B nanoparticles. Int. J. Hydrogen Energy 2015, 40, 7308-7317. [CrossRef]

15. Vinokurov, V.; Stavitskaya, A.; Glotov, A.; Ostudin, A.; Sosna, M.; Gushchin, P.; Darrat, Y.; Lvov, Y. Hallo site nanotube-based cobalt mesocatalysts for hydrogen production from sodium borohydride. J. Solid State Chem. 2018, 268, 182-189. [CrossRef]

16. Ye, W.; Zhang, H.; Xu, D.; Ma, L.; Yi, B. Hydrogen generation utilizing alkaline sodium borohydride solution and supported cobalt catalyst. J. Power Sources 2007, 164, 544-548. [CrossRef]

17. Kong, V.; Kirk, D.; Foulkes, F.; Hinatsu, J. Development of hydrogen storage for fuel cell generators II: Utilization of calcium hydride and lithium hydride. Int. J. Hydrogen Energy 2003, 28, 205-214. [CrossRef]

18. Marrero-Alfonso, E.Y.; Gray, J.R.; Davis, T.A.; Matthews, M.A. Hydrolysis of sodium borohydride with steam. Int. J. Hydrogen Energy 2007, 32, 4717-4722. [CrossRef]

19. Aiello, R. Production of hydrogen from chemical hydrides via hydrolysis with steam. Int. J. Hydrogen Energy 1999, 24, 1123-1130. [CrossRef]

20. Beaird, A.M.; Li, P.; Marsh, H.S.; Al-Saidi, W.A.; Johnson, J.K.; Matthews, M.A.; Williams, C.T. Thermal Dehydration and Vibrational Spectra of Hydrated Sodium Metaborates. Ind. Eng. Chem. Res. 2011, 50, 7746-7752. [CrossRef]

21. Marrero-Alfonso, E.Y.; Gray, J.R.; Davis, T.A.; Matthews, M.A. Minimizing water utilization in hydrolysis of sodium borohydride: The role of sodium metaborate hydrates. Int. J. Hydrogen Energy 2007, 32, 4723-4730. [CrossRef]

22. Baytar, O.; Izgi, M.S.; Horoz, S.; Sahin, O.; Nar, $\mathrm{S}$. $\mathrm{Al}_{2} \mathrm{O}_{3}$ Supported $\mathrm{Co}-\mathrm{Cu}-\mathrm{B}\left(\mathrm{Co}-\mathrm{Cu}-\mathrm{B} / \mathrm{Al}_{2} \mathrm{O}_{3}\right)$ catalyst for hydrogen generation by hydrolysis of aqueous sodium borohydride (NaBH4) solutions. Dig. J. Nanomater. Biostruct. 2019, 14, 673-681.

23. Kim, K.; Kim, T.; Lee, K.; Kwon, S. Fuel cell system with sodium borohydride as hydrogen source for unmanned aerial vehicles. J. Power Sources 2011, 196, 9069-9075. [CrossRef]

24. Kao, H.-Y.; Lin, C.-C.; Hung, C.-J.; Hu, C.-C. Kinetics of hydrogen generation on NaBH 4 powders using cobalt catalysts. J. Taiwan Inst. Chem. Eng. 2018, 87, 123-130. [CrossRef]

25. Wang, X.; Liao, J.; Li, H.; Wang, H.; Wang, R. Preparation of pompon-like Co-B Nano alloy by a room-temperature solid-statereaction as a catalyst for hydrolysis of borohydride solution. Int. J. Hydrogen Energy 2017, 42, 6646-6656. [CrossRef]

26. Wang, M.; Ouyang, L.; Liu, J.; Wang, H.; Zhu, M. Hydrogen generation from sodium borohydride hydrolysis accelerated by zinc chloride without catalyst: A kinetic study. J. Alloys Compd. 2017, 717, 48-54. [CrossRef]

27. Demirci, U.B.; Miele, P. Cobalt in NaBH4 hydrolysis. Phys. Chem. Chem. Phys. 2010, 12, 14651-14665. [CrossRef]

28. Kim, S.J.; Lee, J.; Kong, K.Y.; Jung, C.R.; Min, I.-G.; Lee, S.-Y.; Kim, H.-J.; Nam, S.W.; Lim, T.-H. Hydrogen generation system using sodium borohydride for operation of a 400W-scale polymer electrolyte fuel cell stack. J. Power Sources 2007, 170, 412-418. [CrossRef]

29. Amendola, S.C. A safe, portable, hydrogen gas generator using aqueous borohydride solution and Ru catalyst. Int. J. Hydrogen Energy 2000, 25, 969-975. [CrossRef] 
30. Lai, J.-L.; Luo, W.-J.; Kuan, Y.-D. Preparation of Catalyst for Hydrogen Production Reaction of Sodium Borohydride and Its Effectiveness. Sens. Mater. 2020, 32, 3659. [CrossRef]

31. Akkuş, M.S.; Murathan, H.B.; Özgür, D.Ö.; Özkan, G.; Özkan, G. New insights on the mechanism of vapor phase hydrolysis of sodium borohydride in a fed-batch reactor. Int. J. Hydrogen Energy 2018, 43, 10734-10740. [CrossRef] 